\title{
MOLECULAR CHARACTERIZATION OF SOME CARBAPENEM- RESISTANCE GENES AMONG Pseudomonas aeruginosa ISOLATED FROM WOUND AND BURN INFECTIONS IN DUHOK CITY, IRAQ
}

\author{
MARWA M QAdRi OUMERI and NAJim A. YASSIN \\ Dept. of Medical Microbiology, College of Medicine, University of Duhok, Kurdistan Region, Iraq.
}

(Received: June 10, 2021; Accepted for Publication: June 29, 2021, )

\begin{abstract}
Background Pseudomonas aeruginosa is an opportunistic pathogen causes severe nosocomial infections among burn and wound patients. Multi-drug resistant strains namely carbapenems antibiotics have mentioned worldwide.

Objectives The aim of this study was to know the incidence, patterns of antibiotic susceptibility and molecular characterization of $\boldsymbol{P}$. aeruginosa isolates among wound and burn hospitalized patients.

Methods From September 2019 till September 2020, a total of 524 burn and wound swabs were collected from inpatients at Burn and Emergency Hospital, Duhok city, the Kurdistan region, Iraq. The swabs were cultured and bacterial isolates were identified manually through microbiological tests then by Vitek2 compound system. The isolates were checked for their antibiotic susceptibility patterns then subjected to Polymerase Chain Reaction ( PCR) assay using a set of specific primers for detection of (OprD, blavim, bla IMP) carbapenem-resistance genes.

Result About $60(11.4 \%)$ isolates were identified as $P$. aeruginosa; $33(55 \%)$ from female and $27(45 \%)$ from male. Wound isolates exhibited pretty higher resistance over burn against 24 tested antibiotics. Imipenem; meropenem resistance rates were as $(33.3 \% ; 31.7 \%)$ and $(32.6 \% ; 26.1 \%)$ for burn and wound, respectively. High resistance to piperacillin \& ticarcillin (75\% for both), ticarcillin/clavulanic acid $(66.7 \%)$ and tobramycin $(63.6 \%)$ were noticed in burn isolates. Colistin and piperacillin/tazobactam exhibited very low resistance. PCR assay indicated that $48(96 \%)$ isolates were contained either single or double genes. OprD was predominated $40(80 \%)$ isolates then bla viм gene $8(16 \%)$ isolates, while no bla IMP gene was detected. About 8 isolates were harbored double resistance genes (OprD, bla VIM) simultaneously and unexpectedly $1(12 \%)$ of these isolate was phenotypic carbapenem-susceptible. moreover, 5 phenotypic carbapenem-resistance isolates were not contained any target resistance genes by PCR assay.

Conclusion Occurrence of $\boldsymbol{P}$. aeruginosa as a harbor of multiple carbapenemase resistance genes is increasing over time limiting the treatment options to this serious infection. The data support basic mechanism of imipenem resistance could be mostly via the loss of OprD. Colistin and piperacillin/tazobactam have high efficacy.
\end{abstract}

KEY WORDS: P . aeruginosa, Burn and wound, Carbapenem resistance gene, PCR

\section{INTRODUCTION}

$\boldsymbol{P}$ seudomonas aeruginosa is a vital opportunistic multi-drug resistance pathogen mainly affects immunocompromised patients; severe burns, wounds infections and others (Moradali et al., 2017). This pathogen can tolerate unfavorable environmental factors and somewhat a wide range of temperatures (Moradali et al., 2017). Beside intrinsic resistance to several disinfectant and antibiotic, it has the ability to acquire resistance genes and other virulence factors with increase bacterial count for initiation of pathogenicity and infections (Dash et al., 2019).
Burns and wounds are defined as a painful traumatic injury of the skin breaching integumentary lowering immunity, increased hospital prolonging and ultimately risks of hospital-acquired infections (Bhatt et al., 2015). Frequently, burn and wound infections ends up with sepsis and deaths due to unwise use of systemic antibiotics interventions such as surgical debridement and skin grafting that enables favorable condition for growth of multidrug resistant strains (Dou et al., 2017).

Multidrug Resistant (MDR) strains of $P$. aeruginosa in community have severe impact on limited the availability of therapeutic options. Carbapenems are longer prescribing for 
treatment of MDR $P$. aeruginosa infections when other antibiotics have failed. Carbapenems, such as imipenem and meropenem, are used as last-choice antibiotics for the treatment of multidrug-resistant or panresistant isolates in the recent period. Expansion of carbapenem resistance may considerably compromise their efficiency with main healthcare issues (Tsao et al., 2018). $P$. aeruginosa has the ability to develop chromosomal mutation-related resistance and $\beta$ lactamases-encoded resistance gene acquisition (Alma et al., 2019). The loss of porin Opr D and acquiring resistant genes encoding carbapenemhydrolyzing (carbapenemase) accounted mainstays of resistance (Al-Khudhairy and AlShammari, 2020).

Phenotypic and molecular-based methods have been employment worldwide to find Carbapenem resistant isolates (Miriagou et al., 2010; Nordmann \& Poirel, 2014). Therefore, the purposes of this study were; bacteriological characterization of $P$. aeruginosa isolates from burns and wound hospitalized patients in Duhok city, Kurdistan of Iraq. Also, to investigate the molecular characterization of carbapenem resistance genes by PCR assay using different primers.

\section{MATERIAL AND METHODS}

\subsection{Study setting and subjects}

This prospective study was conducted in the Burn and Emergency Hospital, Duhok city from September 2019 till September 2020. A total of 524 inpatients with various genders and ages having burn injuries and wounds were included. Inclusions were involved wound patient that suffering from diabetic, accident and surgery and not taking antibiotics three days ago also samples taken from burns before applying of disinfectants.

\subsection{Ethical consideration}

Study proposal and informed consent was approved by ethics committee of the College of Medicine, Duhok University and Duhok Public Health Directorate, the Kurdistan Region, Iraq. From all patients, formal consent was taken from their parents/guardians before collecting the samples.

\subsection{Sample collection and processing}

A total of 222 (146 males : 76 females) burn swabs and 302 (126 males : 176 females) wounds swabs (pus or discharge) were aseptically collected. The samples were transported to laboratory within 30 minutes to one hour for bacteriological processing. Swabs were cultured on Blood agar and MacConkey agar and incubated at $37^{\circ} \mathrm{C}$ for 24 hours and extended to $48 \mathrm{hrs}$ if no growth appeared. Purified colonies were first identified through bacteriological reactions and cultural traits (Garcia, 2013; Mushtak et al., 2018). All isolates were then subjected to Vitek2 automated bacterial species identification system (Versalovic et al., 2011) for identification of bacterial species. Confirmed isolates of $P$. aeruginosa were stored at $-20{ }^{\circ} \mathrm{C}$ in nutrient broth supplemented with $20 \%$ glycerol until further processing (Nanvazadeh et al., 2013).

\subsection{Antimicrobial susceptibility Assay}

Most of $P$. aeruginosa isolates subjected to antibiotic susceptibility test through Kirby-Bauer disc diffusion technique (Bauer et al., 1966) according to reference of Clinical and Laboratory Standards Institute (CLSI) (Weinstein et al., 2017). Set of 24 antibiotics discs have been tested (Oxoid) that included: cefoxitin $(30 \mu \mathrm{g})$, amikacin $(30 \mu \mathrm{g})$, ceftriaxone $(10 \mu \mathrm{g})$, cefixime $(5 \mu \mathrm{g})$, gentamicin $(10 \mu \mathrm{g})$, ciprofloxacin $(10 \mu \mathrm{g})$, imipenem $(10 \mu \mathrm{g})$, trimethoprim/ sulphamethoxazole $(10 / 50 \mu \mathrm{g})$, ampicillin $(20 \mu \mathrm{g})$, meropenem $(10 \mu \mathrm{g})$, piperacillin $(100 \mu \mathrm{g})$, peracillin/tazobactam $(100 / 10 \mu \mathrm{g})$, colistin $(10 \mu \mathrm{g})$, ceftazidime $(30 \mu \mathrm{g})$, cefepime $(30 \mu \mathrm{g})$, cefuroxime $(30 \mu \mathrm{g})$, nitrofurantoin $(100 \mu \mathrm{g})$ cefuraxime-axitil $(30 \mu \mathrm{g})$, tobramycin $(10 \mu \mathrm{g})$, ticarcillin $(75 \mu \mathrm{g})$, ticarcillin/clavulanic acid $(75 / 10 \mu \mathrm{g})$, tigecycline $(15 \mu \mathrm{g})$, cefazolin $(30 \mu \mathrm{g})$ and lefofoxacillin $(5$ $\mu \mathrm{g})$. Briefly, an overnight suspension broth culture that corresponding to 0.5 MacFarland Standard were evenly inoculated entire surfaces of Muller-Hinton agar by cotton swab and incubated at $37{ }^{\circ} \mathrm{C}$ for 24 hour. Dishes were later read by detection of growth inhibition zone diameters (millimeter) around each of the antibiotic discs. The zone diameter of drugs was inferred according to Clinical and Laboratory Standards Institute criteria (CLSI) (Weinstein et al., 2017).

\subsection{Extraction of DNA}

Fifty isolates of $P$. aeruginosa were chosen according to their susceptibility patterns to meropenem and imipenem and subjected to molecular characterization (PCR assay). The DNA extraction was done by sweeping a few purified bacterial colonies on blood agar media by utilizing the boiling method (Khosravi et al., 2017). Briefly about 200 microliter of bacterial 
suspension was heated for 20 minutes at $120{ }^{\circ} \mathrm{C}$ followed by high-speed centrifugation ( 3500 rpm for 20 minutes). Supernatants considered as DNA template for PCR amplification. DNA concentration was measured by microvolumes through using the NanoDrop spectrophotometer (Cambridge, England) instrument as described by (Sukumaran, 2011), while purity of DNA were measured by reading the 260/325 absorbance ratios (Desjardins et al., 2011) .

\subsection{PCR Amplification protocol}

Monoplex PCR for carbapenem resistance genes was performed using published primers (Fatemeh and Fereshtesh, 2014; Shariati et al., 2018) for detection of $\mathrm{Opr}$ D, bla VIM and bla IMP, respectively as shown in Table (1).

The master mix of PCR reaction was performed in the final reaction of a total volume of $50 \mu \mathrm{L}$.Each reaction contained PCR Master Red Load Taq Master (2X) (Germany) which contains $200 \mathrm{Mm}$ of each deoxy nucleoside triphosphate (dNTP), (15Mm $\left.\mathrm{MgCl}_{2}\right)$, PCR Buffer $(100 \mathrm{Mm}$ Tris- $\mathrm{HCl}$, pH 8.8, $500 \mathrm{Mm}$, $\mathrm{KCl}, \quad 0.1 \%$ Tween 20), $1.5 \mathrm{U}$ Taq DNA polymerase, $4 \mu \mathrm{L}$ of primer $\left(10\right.$ pmol $\left.\mu l^{-1}\right)$ mixture $(2 \mu \mathrm{L}$ for each forward and reverse primer) and $5 \mu \mathrm{L}$ of DNA template $(50 \mathrm{ng} / \mathrm{ml})$. Amplification of products was done for for bla $V I M$ as following thermal steps and cycling conditions: initial denaturation at $95^{\circ} \mathrm{C}$ for 3 minutes, followed by 30 cycles of denaturation at $95^{\circ} \mathrm{C}$ for $30 \mathrm{sec}$, annealing at $55^{\circ} \mathrm{C}$ for $30 \mathrm{sec}$, and extension at $72^{\circ} \mathrm{C}$ for $1 \mathrm{~min}$; and final extension at $72^{\circ} \mathrm{C}$ for $7 \mathrm{~min}$. for bla IMP: initial denaturation at $95^{\circ} \mathrm{C}$ for $2 \mathrm{~min}$, followed by 30 cycles of denaturation at $95^{\circ} \mathrm{C}$ for $30 \mathrm{sec}$, annealing at $53^{\circ} \mathrm{C}$ for $30 \mathrm{sec}$, and extension at $72^{\circ} \mathrm{C}$ for $1 \mathrm{~min}$; and final extension at $72^{\circ} \mathrm{C}$ for 8 min. For $O p r D$ initial denaturation was at $95^{\circ} \mathrm{C}$ for $2 \mathrm{~min}$, then followed by 30 cycles of denaturation at $95^{\circ} \mathrm{C}$ for $30 \mathrm{sec}$, annealing at $51^{\circ} \mathrm{C}$ for $30 \mathrm{sec}$, and then extension at $72^{\circ} \mathrm{C}$ for 1 min; and final extension at $72^{\circ} \mathrm{C}$ for $1 \mathrm{~min}$. The amplified products were then run in $1 \%$ agarose gel to show specific molecular DNA bands by comparing them to the known molecular weight of the ladder marker.

Table (1): Specific genes, primers sequences and expected products for PCR assays used for carbapenem resistance genes.

\begin{tabular}{|c|c|c|c|c|}
\hline Primer name & Sequence 5-3 & $\begin{array}{l}\text { Amplicon } \\
\text { size (pb) }\end{array}$ & $\begin{array}{c}\text { Optimum } \\
\text { annealing } \\
\text { temperature }\end{array}$ & References \\
\hline OprD & $\begin{array}{l}\text { F 5'-ATGAAAGTGATGAAGTGGAG-3' } \\
\text { R 5' } 5^{\prime} \text {-CAGGATCGACAGCGGATAGT-3' }\end{array}$ & 1329 & $51^{\circ} \mathrm{C}$ & (Shariati et al., 2018) \\
\hline bla IMP & $\begin{array}{l}\text { F 5'-GAAGGCGTTTATGTTCATAC-3' } \\
\text { R 5'-GTATGTTTCAAGAGTGATGC-3' }\end{array}$ & 587 & $53^{\circ} \mathrm{C}$ & $\begin{array}{c}\text { (Fatemeh and } \\
\text { Fereshtesh et al., 2014) }\end{array}$ \\
\hline blaVIM & $\begin{array}{l}\text { F 5'-GTTTGGTCGCATATCGCAAC-3' } \\
\text { R 5'-CTACTCGGCGACTGAGCGAT-3' }\end{array}$ & 645 & $55^{\circ} \mathrm{C}$ & $\begin{array}{l}\text { Fatemeh and Fereshtesh } \\
\text { et al., 2014) }\end{array}$ \\
\hline
\end{tabular}

\subsection{Statistical Analysis}

Statistical analysis was carried out using Graph Pad Prism program (Version 6.01) (Graph Pad Software, USA). The significant difference between variables was determined using Fisher and Chi-square test (Sokal and Rohlf, 2013). Pvalue $<0.05$ was considered a significant.

\section{RESULTS}

A total of $60(11.4 \%)$ isolate of $P$. .aeruginosa were isolated and identified over 524 burns and wound swabs that distributed in various rates among genders, ages and involved hospitals as shown in table (2). 
Table (2): Shows rates of $P$. aerugenosa among genders, ages and involved hospitals

\begin{tabular}{|c|c|c|c|c|c|c|}
\hline \multirow[t]{2}{*}{ Variable } & \multicolumn{4}{|l|}{ Specimens } & & \\
\hline & Burn (26) & Wound (34) & $\begin{array}{l}\text { Total } \\
(60)\end{array}$ & p-value & & \\
\hline Gender & & & & 0.368 & & \\
\hline Male & $9(33.3 \%)$ & $18(66.7 \%)$ & 27 & & & \\
\hline Female & 17 (51.5\%) & $16(48.5 \%)$ & 33 & & & \\
\hline Age & & & & & Total & P.Value \\
\hline $1-9$ & $6(66.7 \%)$ & $3(33.3 \%)$ & 9 & $0.02^{x}$ & & 0.368 \\
\hline 1019 & $5(62.5 \%)$ & $3(37.5 \%)$ & 8 & & 27 & \\
\hline $20-29$ & $8(61.5 \%)$ & $5(38.5 \%)$ & 13 & & 33 & \\
\hline $30-39$ & $3(37.5 \%)$ & $5(62.5 \%)$ & 8 & & & \\
\hline $40-49$ & $3(42.9 \%)$ & $4(51.1 \%)$ & 7 & & & \\
\hline$>=50$ & $1(6.7 \%)$ & $14(93.3 \%)$ & 15 & & & \\
\hline Hospital & & & & & & \\
\hline Burn & $26(43.3 \%)$ & & & & & \\
\hline Emergency & 34 (56.7 \%) & & & & & \\
\hline
\end{tabular}

*- Statistically significant

In current study, burns samples were more infected with $P$. aerugenosa especially among females gender while wounds swabs among males were more harbored isolates but no significant differences between variable genders were noticed (p- value 0.368 ). The highest burn infection rate $(66.7 \%)$ was recorded among age group (0-9) years and the lowest rate $(6.7 \%)$ was in age ( $>=50$ years). Inversely, in wounds the age $(>=50$ years) was the highest rate (93.3\%) and the lowest rate $(33.3 \%)$ was seen among (0-9 years) and statistically was significant $(\mathrm{P}$. value 0.02$)$.

Concerning antibiotic susceptibility test, generally all isolates from wound sources were exhibited relatively higher resistance rates over burn isolates against (24) tested antibiotics. Nearly, all burn swabs isolates showed lower resistance rates except for piperacillin and ticarcillin (75\%), ticarcillin/clavulanic acid (66.7
$\%)$ and tobramycin (63.6 \%). While, more resistance rates were seen among wound swabs isolates notably to tigecycline (86.7\%), cefazolin (76.9\%), ampicillin (62.5\%) and levofloxacin (60\%). Colistin and piperacillin/tazobactam were more efficient antibiotics against all isolates from burn followed by wound swabs as in table (2).

Table (3) shows molecular detection of carbapenem resistance genes among 50 isolates that were phenotypically resistant and sensitive to meropenem and imipenem and subjected to PCR assay for presence and absence of $O p r D$, bla VIM and bla IMP genes. Opr D was common accounted $32(85 \%)$ mainly among meropenem and imipenem resistant isolates while sensitive isolates also contained it. bla VIM gene was found among $7(17.5 \%)$ isolates, while bla IMP was not detected among studied isolates.

Table (3): Antibiotic susceptibility patterns of $P$. a aeruginosa from burns and wounds

\begin{tabular}{|c|c|c|c|c|}
\hline \multirow[b]{2}{*}{ Antibiotics } & \multicolumn{2}{|c|}{ Burns Isolates } & \multicolumn{2}{|c|}{ Wounds Isolates } \\
\hline & Resistance (\%) & Susceptible (\%) & Resistance (\%) & Susceptible (\%) \\
\hline Amikacin & 33.3 & 66.7 & 33.3 & 66.7 \\
\hline Ampicillin & 37.5 & 72.5 & 62.5 & 37.5 \\
\hline Cefazolin & 23 & 77 & 76.9 & 23.1 \\
\hline Cefepime & 38.5 & 61.5 & 26.9 & 73.1 \\
\hline Cefixime & 39.4 & 60.6 & 54.5 & 45.5 \\
\hline Cefoxitin & 36.9 & 63.1 & 63 & 37 \\
\hline Ceftazidime & 30 & 70 & 23.3 & 76.7 \\
\hline Ceftriaxone & 37 & 63 & 56.5 & 43.5 \\
\hline Cefuraxime & 45.2 & 54.8 & 54.8 & 45.2 \\
\hline Cefuraxime axetil & 45.2 & 54.8 & 54.8 & 45.2 \\
\hline
\end{tabular}


Journal of University of Duhok, Vol. 24, No.1 (Pure and Eng. Sciences), Pp136-144, 2021

\begin{tabular}{ccccc}
\hline Ciprofloxacin & 35 & 65 & 30 & 70 \\
\hline Colistin & 0 & 100 & 8.3 & 91.7 \\
\hline Gentamicin & 39 & 61 & 23.7 & 72.3 \\
\hline Imipenem & 33.3 & 66.7 & 31.7 & 68.3 \\
\hline Levofloxacin & 13.3 & 86.7 & 60 & 40 \\
\hline Meropenem & 32.6 & 67.4 & 26.1 & 39.9 \\
\hline Nitrofurantion & 37 & 63 & 60.9 & 25 \\
\hline Piperacillin & 75 & 25 & 11.1 & 75.9 \\
\hline Piperacillin/ Tazobactam & 11.1 & 88.9 & 25 & 13.3 \\
\hline Ticarcillin & 75 & 25 & 25 & 81.3 \\
\hline Ticarcillin/ Clavulanic acid & 66.7 & 33.3 & 86.7 & 42.6 \\
\hline Tigecycline & 13.3 & 86.7 & 18.7 & 57.4 \\
\hline Tobramycin & 63.6 & 36.8 & & \\
\hline Trimethoprim/ & 36.2 & 63.8 & & \\
\hline Sulfamethoxazol & & & & \\
\hline
\end{tabular}

Table (4): Molecular Detection of Carbapenem resistance genes in 50 isolates of $P$. aeruginosa Results 50 isolate of $P$. aerugenosa

\begin{tabular}{|c|c|c|c|c|c|c|}
\hline & \multicolumn{3}{|c|}{$\begin{array}{c}40 \text { isolate } \\
\text { imipenem \& meropenem resistant }\end{array}$} & \multicolumn{3}{|c|}{$\begin{array}{c}10 \text { isolates } \\
\text { imipenem susceptible }\end{array}$} \\
\hline & bla vIM & Opr D & bla ${ }_{I M P}$ & bla VIM & Opr D & bla ${ }_{I M P}$ \\
\hline+ ve & $7(17.5 \%)$ & $32(80 \%)$ & 0 & $1(10 \%)$ & $8(80 \%)$ & 0 \\
\hline- ve & $33(82.5 \%)$ & $8(20 \%)$ & 0 & $9(90 \%)$ & $2(20 \%)$ & 0 \\
\hline
\end{tabular}

From another hand, about $8 / 100$ isolates were found to contain double resistance genes $(\mathrm{Opr}$ $D+$ bla $\left._{V I M}\right)$ simultaneously that occurred more within imipenem resistant isolates as in table
(4). Some of the isolates that expressed resistance phenotypically to both imipenem and meropenem but they were not contained any target resistance genes as in table (5).

Table (5): Distribution of double resistance genes $\left(O p r D+b l a_{V I M}\right)$

\begin{tabular}{ccc}
\hline Target gene & Phenotypic Resistance spectrum & No. (\%) \\
\hline Opr D+ bla $V I M$ & imipenem(R)+ meropenem(R) & $5(62.5)$ \\
& & $2(25)$ \\
\cline { 2 - 3 } & imipenem(R)+ meropenem(S) & $1(12.5)$ \\
\cline { 2 - 3 } & imipenem(S)+ meropenem(S) & $8(100)$
\end{tabular}

R: resistance, S:sensitive

Table (6): Carbapenem-resistance Isolates without target-resistance genes

\begin{tabular}{ccc}
\hline Target genes & Phenotypic Resistance spectrum & No. (\%) \\
\hline Opr $D-v e$ & imipenem(R)+ meropenem(R) & $2(33)$ \\
bla ${ }_{V I M}-v e$ & imipenem(R) only & $4(67)$ \\
bla IMP $_{M}-v e$ & Total & $6(100)$ \\
\cline { 2 - 3 }
\end{tabular}

\section{DECUSSION}

The present research is useful in providing data on the prevalence of carbapenem resistant $P$ . aeruginosa, particularly in burn and wounds of nosocomial infections. Sixty $(11.4 \%) P$. aeriginosa isolate were diagnosed from burns and wounds infections. Similar study done in Duhok city; Iraq found $12.7 \%$ of $P$. aeruginosa isolates were from wounds (Yassin et al., 2014). Other studies in Iraq, announced $12.4 \%$ in Najaf, $12 \%$ in Baghdad and $18 \%$ in Wasit city
(Al-Huraishi, 2016; Hussein \& Shamkhi, 2018; Al-khudhairy \& Al-Shammari, 2020). Low rate $3.95 \%$ was reported by Anoar et al., 2014, in Sulaimaniyah City, Iraq. These differences and diversity in proportions might be due the type of inclusion criteria for enrolled patients with various as gender, specimen types, kind of test used in isolation and usage of preventive handling that determines the percentage (Hussein \& Shamkhi, 2018). In the current study males were more affected than females and this in line with a study done in 
Sulaimaniyah city, Iraq showed female accounted $57 \%$ and male $43 \%$ (Othman et al., 2014). Our results were in line with two studies done in Iran; in Shiraz and Ahwaz city they found female; male were $53 \% ; 26 \%$ and $56 \%$ and $41 \%$ (Anvarinejad et al., 2014; Khosravi et al., 2017) respectively. Disagree to Qader et al., 2020, who recorded $63.5 \%$ and $36.4 \%$ among males and females respectively, in Duhok and Erbil Hospitals/Iraq. Female gender is spending more their times in the kitchen in our society so they are more likely to be at risk to getting burns, as well as they are more exposed to suicide because of either domestic violence or marital issues. Two hospitals located in Duhok city were involved in the current study; Emergency Hospital comprised $56.7 \%$ isolates and Burn Hospital $43.3 \%$ isolates, indicating that large hospital was harbored more isolates of this pathogen. Similar results reported by studies done performed by (Aljanaby \& aljanaby, 2017) in Kufa city, Iraq and (Sales et al., 2017; Shaaban et al., 2017) in Iran. Many staff members, carries states and infected patients belong large hospitals may transiently become contaminated and shed pathogens to immunocompromised patients (Douglas, 2001)

In this study less resistance rates were seen toward imipenem; meropenem $(33.3 \% ; 31.7 \%)$ and $(32.6 \% ; 26.1 \%)$ from burn and wound isolates, respectively. This results needs to be taken in considerations in this setting. Similarly, Jaafar et al., (2014) in Baghdad city, Iraqi announced that imipenem resistance was $24.4 \%$ while meropenem was $17.24 \%$. Hussein et al., (2018) in Wasit city, Iraqi, revealed the same percentage $(34.95 \%)$ of resistance found toward imipenem and meropenem. Different from results of the present study, Al-Shara, (2013) in Najaf, Iraq, reported less resistance against imipenem and meropenem $7.4 \%$ and $14.8 \%$, respectively. A recent study by Al-khudhairy \& Al-Shammari, (2020) in Iraq stated that imipenem resistance rate was $12.4 \%$. Farajzadeh Sheikh et al., (2014) in Ahwaz city, Iran mentioned meropenem resistance was $58.7 \%$. later, another two studies in Iran showed alarming increasing rates as $97 \%$ and $96 \%$ in Isfahan and Tehran (Radan et al., 2016; Mahmood Saffari et al., 2016) respectively. Some reports from European countries stated increased frequency of carbapenem-resistant $P$. aeruginosa from $1 \%$ to $28 \%$ between 2002 till 2006 (Hong et al., 2015; Bassetti et al., 2018). Unfortunately, carbapenemase -producing organisms will develop a resistance to both imipenem and meropenem in addition to the quality of hygiene and duration of hospital stays for patients (Chairat et al., 2019). The resistance rate to colistin was $8.3 \%$ in this work. Colistin resistance is not dependent upon bacterial metabolic activity and also the acquired resistance is rare (Ece et al., 2014). The current data agree with Hussein et al., 2018, who recorded colistin resistance rate $2.78 \%$ in Wasit city, Iraq. Less rate of colistin resistance found in study in Tabriz, Iran revealed a resistance rate 2\% (Goli et al., 2016). Additionally good data obtained by Al-khudhairy \& Al-Shammari, 2020 in Iraq claimed no resistance rate to colistin $0 \%$. The high price of colistin, its nephrotoxicity and limited use outside of the hospitals might explain its higher effectivity (Hussein et al., 2018). Effective MDR $P$. aeruginosa therapies may be limited, requiring doctors to be familiar with older antibiotics (i.e. colistin) which are expected to be released in the near future for general use.

In this study, 48 (96\%) isolate were contained either single or double genes. $\operatorname{OprD}$ gene was common comprised $40(80 \%)$ isolate included both resistant and susceptible isolates. This result coincides with other studies that searched for $\operatorname{OprD}$ gene among resistant and sensitive isolates for instance; Amin et al., ( 2005) in Sweden; Ocampo-Sosa et al., (2012) in Spanish and Shariati et al., (2018) in Iran. Every loss of OprD expression from the outer membrane greatly reduces the susceptibility of $P$. aeruginosa to carbapenem (El Amin et al., 2005). In addition, multi-drug efflux pumps properties also play a significant role in resistance (Livermore, 2001). In our results, the incidence of bla ${ }_{V I M}$ gene was detected among 8 $(16 \%)$ isolates and it was illustrated that this gene was more distributed among those isolates that were resistant to both imipenem and meropenem. This already was higher as $75 \%$ that stated by Shaaban et al., ( 2017) in Egypt. More high rate in Wasit city; Iraq was $94 \%$ (Hussein \& Shamkhi, 2018). In contrast, only 1 out of 81 isolates mentioned by van Burgh et al., 2019 in Kurdistan, Iraq. In Turkey, 1\% of isolates were harbored bla ${ }_{V I M}$ gene (Ozgumus et al., 2007). Because $P$. aeruginosa is a leading cause of nosocomial infections, thus plasmids carrying this gene can be circulated and easily transferred between the strains in close proximity, leading to multi-drug resistant microorganisms (Turk, 2011). Regardless of 
their phenotypic resistance patterns, bla IMP gene was not detected among all selected isolates by PCR assay. Another study by Al-Ouqaili, (2016) in Iraq, also not detected this gene. The results agree with Rodríguez-Martínez et al., (2009) that have not detected it. While disagreeing with two studies in Iran; Radan et al., (2016) reported $74.3 \%$ and Salimi \& Eftekhar, (2014) accounted $56.25 \%$. Not detecting of this gene might be due to geographical variations and use of certain types of antibiotics that playing a role in selecting the type of Metallo- $\beta$-Lactamase (MBL) producing strains (Turk, 2011). In this study, 8 isolates were found to contain double resistance genes $\left(O p r D+b l a{ }_{V I M}\right)$ simultaneously that occurred more frequently among isolates that showed resistance to both imipenem and meropenem and remarkably within one susceptible isolate. The striking finding is that some isolates that expressed resistance phenotypically to imipenem and meropenem together and individually were not contained any target resistance genes. This might be due to the presence of other resistance genes than targeted or other carbapenem resistance mechanisms as $P$ - aeruginosa often accumulate different resistance mechanisms that contribute to carbapenem resistance (Rodríguez-Martínez et al., 2009). The differences in the prevalence of $P$ - aeruginosa genes between geographic locations could be because of climate (moisten) of each place, civilizations, nutrition, and hospital's hygiene (Karimian et al., 2012; Rasol, 2013; Qader et al., 2020).

The study concludes that the emergence of $P$ - aeruginosa as a reservoir of multiple carbapenemases resistance genes is increasing over time limiting the treatment options to this serious infection. The data support basic mechanism of imipenem resistance could be mostly via the loss of $O p r D$. Colistin and piperacillin/tazobactam have high efficacy.

\section{REFEFERNCES}

Al-Huraishi, M. A. M. (2016). Molecular detection of multidrug resistance Acinetobacter baumannii from different clinical samples (Doctoral dissertation, MSc Thesis. College of Medicine, Al-Nahrain University, Iraq).

Aljanaby, A. A. J., \& Aljanaby, I. A. J. (2017). Profile of Antimicrobial Resistance of Aerobic Pathogenic Bacteria isolated from Different Clinical Infections in Al-Kufa Central Hospital-Iraq During period from 2015 to
2017. Research Journal of Pharmacy and Technology, 10(10), 3264-3270.

Al-khudhairy, M. K., \& Al-Shammari, M. M. M. (2020). Prevalence of metallo- $\beta$-lactamaseproducing Pseudomonas aeruginosa isolated from diabetic foot infections in Iraq. New microbes and new infections, 35, 100661.

Alma L, Rosa D,Elena B,Claudia J, Yolanda S, Miguel C. et al., (2019). Characterization of antimicrobial resistance mechanisms in carbapenem-resistant Pseudomonas aeruginosa carrying IMP variants recovered from a Mexican Hospital. Infection and Drug Resistance. 185.239-27.

Al-Ouqaili, M. T. (2018). Identification of an OprD and blaIMP gene-mediated carbapenem resistance in Acinetobacter baumannii and Pseudomonas aeruginosa among patients with wound infections in Iraq. Asian Journal of Pharmaceutics (AJP):12(03).

Al-Shara, J. M. R. (2013). Phenotypic and molecular detecting of carbapenem resistant Pseudomonas aeruginosa in Najaf Hospitals (Doctoral dissertation, Ph. D. Thesis. Sc, University of Kufa. Iraq).

Amin, N. E., Giske, C. G., Jalal, S., Keijser, B., Kronvall, G., \& Wretlind, B. (2005). Carbapenem resistance mechanisms in Pseudomonas aeruginosa: alterations of porin OprD and efflux proteins do not fully explain resistance patterns observed in clinical isolates. Apmis, 113(3), 187-196.

Anoar KA, Ali FA, Omar SA, (2014). Detection of metallo- $\beta$-lactamase enzyme in some Gram negative bacterial isolated from burn patients in Sulaimani City, Iraq. European Scientific journal,10:1857-81.

Anvarinejad, M., Japoni, A., Rafaatpour, N., Mardaneh, J., Abbasi, P., Shahidi, M. A., et al. (2014). Burn patients infected with metallo-beta-lactamase-producing Pseudomonas aeruginosa: Multidrug-resistant strains. Archives of trauma research, 3(2).

Bassetti M, Vena A, Croxatto A, Righi E, Guery B. (2018). How to manage Pseudomonas aeruginosa infections. Drugs Context, 7:212527.

Bauer, A. W., Kirby, W. M., Sherris, J. C., and Turck, M. (1966). Antibiotic susceptibility testing by a standardized single disc method. Am J clin pathol; 45(4): 493-496.

Bhatt, P., Rathi, K. R., Hazra, S., Sharma, A., \& Shete, V. (2015). Prevalence of multidrug resistant Pseudomonas aeruginosa infection in burn patients at a tertiary care center. Indian J Burns 2015;23 (1):56-59.

Chairat, S., Ben Yahia, H., Rojo-Bezares, B., Sáenz, Y., Torres, C., \& Ben Slama, K. (2019). High prevalence of imipenem-resistant and metallo-beta-lactamase-producing 
Pseudomonas aeruginosa in the Burns Hospital in Tunisia: detection of a novel class 1 integron. Journal of Chemotherapy, 31(3), 120-126.

Dash C, Sahu S, Sinha S, \& Nayak, P. (2019). Pseudomonas aeruginosa in burn infections and its antimicrobial resistance. $\mathrm{J}$ Evid Based Med Healthc. 2019; 6(26), 1772-1776. DOI: 10.18410/jebmh/2019/361.

Desjardins , P.R and D. S. Conklin, D.S (2011). "Microvolume quantitation of nucleic acid," Current Protocols in Human Genetics, 93: 3J.1-A.3J.

Dou Y, Huan J, Guo F. (2017). Pseudomonas aeruginosa prevalence, antibiotic resistance and antimicrobial use in Chinese burn wards from 2007 to 2014. J Int Med Res,45 (3):11241137.

Douglas, M.W., Mulholland, K., Denyer, V. and Gottlieb, T. (2001). Multi-drug resistant P.aeruginosa outbreak in a burns unit an infection control study. Burns, 27(2): 131-135.

Ece, G., Samlioglu, P., Atalay, S., \& Kose, S. (2014). Evaluation of the in vitro colistin susceptibility of Pseudomonas aeruginosa and Acinetobacter baumannii strains at a tertiary care centre in Western Turkey. Le infezioni in medicina, 22(1), 36-40.

Farajzadeh Sheikh A, Rostami S, Jolodar A, Tabatabaiefar MA, Khorvash F, Saki A, et al. (2014). Detection of Metallo-Beta Lactamases among Carbapenem-Resistant Pseudomonas aeruginosa. Jundishapur $\mathrm{J}$ Microbiol. 7(11):12289.

Fatemeh S., Fereshteh E. (2014). Prevalence of blaIMP and blaVIM gene carriage in metallo$\beta$-lactamase-producing burn isolates of Pseudomonas aeruginosa in Tehran Turk J Med Sci, 44:511-514.

Garcia, M. M. (2013). Carbapenemases: A real threat. APUA Newsl, 31, 4-6.

Goli HR, Nahaei MR, Ahangarzadeh Rezaee M, et al. (2016). Emergence of colistin resistant Pseudomonas aeruginosa at Tabriz hospitals, Iran. Iranian journal of microbiology. 8(1): 629.

Hong DJ, Bae IK, Jang IH, Jeong SH, Kang HK, Lee K, (2015). Epidemiology and characteristics of metallo- $\beta$-lactamase producing Pseudomonas aeruginosa. Infection \& chemotherapy.47:81-97.

Hussein, Z. K., \& Shamkhi, I. J. (2018). Detection of bla VIM1 gene in carbapenem resistant Pseudomonas aeruginosa isolated from clinical samples in Wasit province hospitals. Basrah J Vet Res, 17, 30-44.

Hussein, Z. K., Kadhim, H. S., \& Hassan, J. S. (2018). Detection of New Delhi metallo-betalactamase-1 (blaNDM-1) in carbapenemresistant pseudomonas aeruginosa isolated from clinical samples in Wasit hospitals. Iraqi JMS. 2018; 16 (3): 239-246. doi: 10.22578. IJMS, 16(3).

Jaafar, Z. M., Dhahi, M. A., Abd, A. K. H., \& Jaafar, S. M. (2014). Molecular identification and antibiotics resistance genes profile of Pseudomonas aeruginosa isolated from Iraqi patients. African Journal of Microbiology Research, 8(21), 2183-2192.

Karimian, A., Momtaz, H., and Madani, M. (2012). Detection of uropathogenic E.coli virulence factors in patients with urinary tract infections in Iran. African Journal of Microbiology Research,6 (39): 6811-6816.

Khosravi, A. D., Motahar, M., \& Abbasi Montazeri, E. (2017). The frequency of class1 and 2 integrons in Pseudomonas aeruginosa strains isolated from burn patients in a burn center of Ahvaz, Iran. PloS one, 12(8), e0183061.

Livermore, D. M. (2001). Of Pseudomonas, porins, pumps and carbapenems. Journal of Antimicrobial Chemotherapy, 47(3), 247-250.

Mahmood Saffari, F. F., Pourbabaee, M., \& Zibaei, M. (2016). Evaluation of metallo- $\beta$ lactamase-production and carriage of bla-vim genes in Pseudomonas aeruginosa isolated from burn wound infections in Isfahan. Archives of trauma research, 5(4).

Miriagou, V., Cornaglia, G., Edelstein, M., Galani, I., Giske, C. G., Gniadkowski, M., et al. (2010). Acquired carbapenemases in Gramnegative bacterial pathogens: detection and surveillance issues. Clinical microbiology and infection, 16(2), 112-122.

Moradali, M. F., Ghods, S., \& Rehm, B. H. (2017). Pseudomonas aeruginosa Lifestyle: A Paradigm for Adaptation, Survival, and Persistence. Frontiers in cellular and infection microbiology, 7, 39.

Mushtak T. S., Ahmed S. J, Amin S. B.(2018). Identification of an $\operatorname{OprD}$ and bla IMP Genemediated Carbapenem Resistance in Acinetobacter baumannii and Pseudomonas aeruginosa among patients with Wound Infection in Iraq.DOI: 10.22377/ajp.v12103.2634.

Nanvazadeh, F., Khosravi, A. D., Zolfaghari, M. R., \& Parhizgari, N. (2013). Genotyping of Pseudomonas aeruginosa strains isolated from burn patients by RAPD-PCR. Burns, 39(7), 1409-1413.

Nordmann, P., \& Poirel, L. (2014). The difficult-tocontrol spread of carbapenemase producers among Enterobacteriaceae worldwide. Clinical Microbiology and Infection, 20(9), 821-830.

Ocampo-Sosa, A. A., Cabot, G., Rodríguez, C., Roman, E., Tubau, F., Macia, M. D., et al. (REIPI. (2012). Alterations of OprD in 
carbapenem-intermediate and-susceptible strains of Pseudomonas aeruginosa isolated from patients with bacteremia in a Spanish multicenter study. Antimicrobial agents and chemotherapy, 56(4), 1703-1713.

Othman, N., Babakir-Mina, M., Noori, C. K., \& Rashid, P. Y. (2014). Pseudomonas aeruginosa infection in burn patients in Sulaimaniyah, Iraq: risk factors and antibiotic resistance rates. The Journal of Infection in Developing Countries, 8(11), 1498-1502.

Ozgumus, O. B., Caylan, R., Tosun, I., Sandalli, C., Aydin, K., \& Koksal, I. (2007). Molecular epidemiology of clinical Pseudomonas aeruginosa isolates carrying IMP-1 metallo- $\beta$-lactamase gene in a university hospital in Turkey. Microbial Drug Resistance, 13(3), 191-198.

Qader, M. K., Solmaz, H., \& Merza, N. S. (2020). Molecular Typing and Virulence Analysis of Pseudomonas Aeruginosa Isolated From Burn Infections Recovered From Duhok and Erbil Hospitals/Iraq. UKH Journal of Science and Engineering, 4(2), 1-10.

Radan, M., Moniri, R., Khorshidi, A., Gilasi, H., Norouzi, Z., Beigi, F., et al. (2016). Emerging carbapenem-resistant Pseudomonas aeruginosa isolates carrying blaIMP among burn patients in Isfahan, Iran. Archives of Trauma Research,, 5(3).

Rodríguez-Martínez, J. M., Poirel, L., \& Nordmann, P. (2009). Molecular epidemiology and mechanisms of carbapenem resistance in Pseudomonas aeruginosa. Antimicrobial agents and chemotherapy, 53(11), 4783-4788.

Sales, A., Fathi, R., \& Mobaiyen, H. (2017). Molecular Study of the Prevalence of CTXM1, CTX-M2, CTXM3 in Pseudomonas aeruginosa Isolated from Clinical Samples in Tabriz Town, Iran. Electronic J Biol, 13(3), 253-9.

Salimi, F., \& Eftekhar, F. (2014). Prevalence of blAbstractP and blaVIM gene carriage in metallo-lbeta-lactamase-producing burn isolates of Pseudomonas aeruginosa in Tehran. Turkish journal of medical sciences, 44(3), 511-514.

Shaaban, M., Al-Qahtani, A., Al-Ahdal, M., \& Barwa, R. (2017). Molecular characterization of resistance mechanisms in Pseudomonas aeruginosa isolates resistant to carbapenems. The Journal of Infection in Developing Countries, 11(12), 935-943.
Shariati, A., Azimi, T., Ardebili, A., Chirani, A. S., Bahramian, A., Pormohammad, A., et al. (2018). Insertional inactivation of oprD in carbapenem-resistant Pseudomonas aeruginosa strains isolated from burn patients in Tehran, Iran. New microbes and new infections, 21, 75-80.

Sokal, R. R. and Rohlf, F.J. (2013). Introduction to Biostatistics, 2nd ed. Dover. NewYork, 10991121.

Sukumaran, S. (2011). "Concentration determination of nucleic acids and proteins using the micro-volume bio-spec nano spectrophotometer," Journal of Visualized Experiments, 1:2699.

Tsao, L. H., Hsin, C. Y., Liu, H. Y., Chuang, H. C., Chen, L. Y., \& Lee, Y. J. (2018). Risk factors for healthcare-associated infection caused by carbapenem-resistant Pseudomonas aeruginosa. Journal of microbiology, immunology and infection, 51(3), 359-366.

Turk, M. (2011). Carbapenem resistant pseudomonas aeruginosa: oprd downregulation and the types of metallo- $\beta$-lactamases produced. University of Balamand, 56-62.

van Burgh, S., Maghdid, D. M., Ganjo, A. R., Mansoor, I. Y., Kok, D. J., Fatah, M. H., et al. (2019). PME and other ESBL-positive multi-resistant Pseudomonas aeruginosa isolated from hospitalized patients in the region of Kurdistan, Iraq. Microbial Drug Resistance, 25(1), 32-38.

Versalovic, J., Carroll, K. C., Funke, G., Jorgensen, J. H., Landry, M. L., \& Warnock, D. W. (2011). Manual of clinical microbiology, ASM Press. Washington, DC [Google Scholar].

View at: Publisher Site | Google Scholar

Weinstein, M., Patel, J., Bobenchik, A. (2017). Clinical and laboratory standards institute. Performance Standards for Antimicrobial Susceptibility Testing, 27th ed.; Clinical and Laboratory Standards Institute: Wayne, PA, USA, 296.

Wilson, M. L., Mitchell, M., Morris, A. J., Murray, P. R., Reimer, L. G., Reller, L. B., et al. (2007). Principles and procedures for blood cultures; approved guideline. CLSI document M47-A. Clinical and Laboratory Standards Institute, Wayne, PA.

Yassin, N. A., Khalid, H. M., \& Hassan, A. O. (2014). Prevalence of metallo- $\beta$-lactamase producing Pseudomonas aeruginosa in wound infections in Duhok City, Iraq. Int J Res Med Sci, 2,

1576-9. 